\title{
THE EFFECT OF MAIZE-SOYBEAN INTERCROPPING SYSTEMS ON A SET OF TECHNOLOGICAL AND PHYSIOLOGICAL PROPERTIES
}

\author{
ÖNER, F. ${ }^{*}-$ AYKUTLU, H. M. \\ Agricultural Faculty, Department of Field Crops, Ordu University, 52200 Ordu, Turkey \\ (phone: +90452 2265200 int.:6345; fax: +90 452 2346632) \\ *Corresponding author \\ e-mail:fatihoner38@gmail.com \\ (Received 14 ${ }^{\text {th }}$ Nov 2018; accepted $16^{\text {th }}$ Jan 2019)
}

\begin{abstract}
This study set out to determine which seeding rate produces the maximum grain yield through the monocropping and intercropping of maize and soybeans using different seeding rates on the research and land of the Faculty of Agriculture, Ordu University, in 2016. To this end, the study used a randomized block experimental design with three replications. The treatments included a sole crop of maize, a sole crop of soybean, one row of soybean intercropped with one row of maize, two rows of soybeans intercropped with one row of maize, three rows of soybeans intercropped with one row of maize, one row of soybean intercropped with two rows of maize, and one row of maize intercropped with three rows of soybean. According to the results on maize, the chlorophyll concentration index ranged from 45.50 to 50.93 , leaf area from 360.51 to $510.19 \mathrm{~cm}^{2}$, ash content from 5.76 to $9.30 \%$, protein content from 9.26 to $10.77 \%$, crude fat content from 3.35 to $4.85 \%$, palmitic acid content from 12.17 to $13.12 \%$, stearic acid content from 1.98 to $2.44 \%$, oleic acid content from 23.86 to $24.95 \%$, linoleic acid content from 58.97 to $60.90 \%$, linolenic acid content from 0.91 to $1.13 \%$, unsaturated fatty acid content from 84.62 to $85.84 \%$, saturated fatty acid content from 14.15 to $15.37 \%$, unsaturated to saturated fatty acid ratio from 5.50 to $6.08 \%$, and grain yield from 32.01 to $89.512 \mathrm{~kg} \mathrm{ha}^{-1}$. According to the results on soybean, the chlorophyll concentration index ranged from 42.33 to 44.43 , leaf area from 32.41 to 41.38 $\mathrm{cm}^{2}$, ash content from 9.67 to $10.82 \%$, protein content from 42.92 to $45.38 \%$, crude fat content from 19.65 to $20.77 \%$, palmitic acid content from 10.39 to $10.77 \%$, stearic acid content from 3.81 to $4.28 \%$, oleic acid content from 19.86 to $20.29 \%$, linoleic acid content from 58.01 to $58.98 \%$, linolenic acid content from 6.58 to $7.07 \%$, unsaturated fatty acid content from 84.92 to $85.54 \%$, saturated fatty acid content from 14.45 to $14.99 \%$, unsaturated to saturated fatty acid ratio from 5.66 to $5.91 \%$, grain yield from 10.36 to $61.11 \mathrm{~kg} \mathrm{ha}^{-1}$, and the Land Equivalent Ratio (LER) from 1.03 to 1.21 . Considering all the properties investigated and LER together, three rows of soybean intercropped with one row of maize were found to be the most appropriate intercropping system.
\end{abstract}

Keywords: crude fat content, fatty acids, leaf area, LER, protein content

\section{Introduction}

Maize or corn occupies an important place both in Turkey and throughout the world because it has greater adaptability and the highest yield among cereals. $35 \%$ of the maize produced in Turkey is used in human nutrition, 30\% in animal nutrition, $20 \%$ in the feed industry, and 15\% in other areas (Gençtan et al., 1995). Maize is also a good source of energy because the majority of maize (corn grains) is composed of starch. Not only is corn starch obtained from maize, but also corn gluten meal and bran are manufactured from maize embryos for use in the oil and feed industry (Hallauer, 2001). The widespread use of oil and starch as bioenergy and the high yield of the maize plant have led to maize manufacture in every region where climatic conditions allow (Abbasi and Abbasi, 2010). 
Soybean plants consist of 18 to $26 \%$ fat and $40 \%$ protein. The quality of soybean oil is increased by the high amount of oleic and linoleic fatty acids and the low amount of linolenic fatty acids. By-products obtained from soybean (flour, lecithin, protein, and fat) are used as raw materials in the industry (Cole and Erdahl, 2018). A wide range of products are manufactured from soybeans, including coffee cream, cooking oil, margarine, mayonnaise, medication, pharmaceuticals, salad dressing, anti-corrosion agents, anti-static agents, construction materials, ink printing materials, epoxies, fungicides, soap, detergents, bread, confectionery, biscuits, soya coffee, packaging foils, antibiotics, textiles, cat and dog foods, and fish feed (Endres, 2001).

In the world and in Turkey, the limited possibility of increasing the number of cultivable agricultural areas and the rapid increase in population have caused to agricultural workers to seek ways to exploit the maximum amount of agricultural land. Intercropping is one of these ways. Intercropping is recommended in order to produce greater and more balanced yield from unit area and to bolster defence against weeds (Acar et al., 2006).

Intercropping is an effective alternative for the prevention of loss within a complete growing season. The objective of intercropping is to create beneficial biological interactions between plants. Using legumes, it improves soil fertility through biological nitrogen fixation and ensures better soil conservation than monocropping. Ecological resources can be used better and far superior efficiency can be achieved in intercropping compared to monocropping. Having said that, there is a competition between intercropped inter- and intra-species for water, light, and nutrients. Therefore, it is of utmost importance to determine appropriate species and the ratio of crop mixtures in order to gain the expected benefit from intercropping (Lithourgidis et al., 2011).

Against this background, the purpose of the present study is to identify the effects of sole-cropped and intercropped maize and soybeans on a set of technological and physiological properties, which are manufactured to obtain material in primarily human nutrition and secondly animal nutrition.

\section{Material and method}

The trial was conducted on the research and land of the Faculty of Agriculture, Ordu University, in 2016 . The land is located at $40^{\circ} 58^{\prime} 13.4^{\prime \prime} \mathrm{N}$ latitude and $37^{\circ} 56^{\prime} 16.6^{\prime \prime} \mathrm{E}$ longitude at an altitude of three meters (Fig. 1).

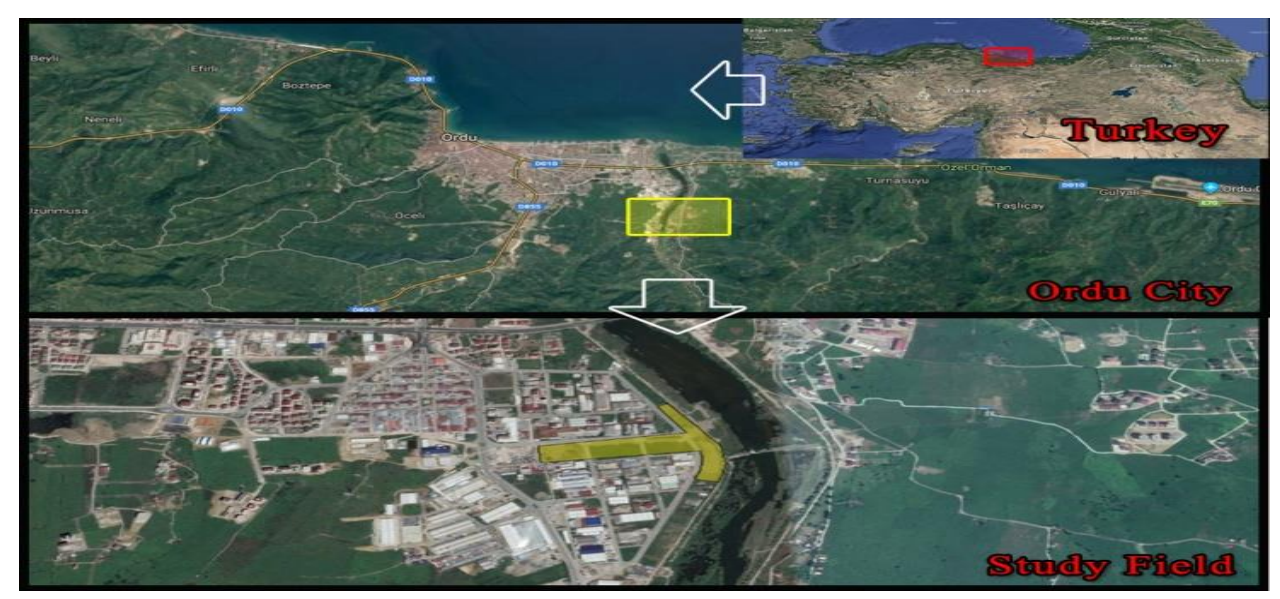

Figure 1. Location of the study field 
During the vegetation period of maize and soybean, the total precipitation at the trial site is $474.7 \mathrm{~mm}$, the average temperature is $19.7^{\circ} \mathrm{C}$, and the average humidity is $74.3 \%$. During the vegetation period of maize and soybean in 2016 , the total precipitation at the trial site was $624 \mathrm{~mm}$, the average temperature was $22.1^{\circ} \mathrm{C}$, and the average humidity was $68.3 \%$. The total precipitation and average temperature recorded in the year of trial 2016 are above the average of long years (1965-2015) and the average humidity is below the average of long years (1965-2015). According to the results of soil analysis, the soil sampled from the trial site is clayey and neutral in terms of soil reaction and has a moderate amount of organic matter. Its less chalky soil is also less chalky and more saline.

The present study used Arısoy soybean seed variety supplied from the Black Sea Agricultural Research Institute, and SY Inove maize seed supplied from a private seed company. The trial was established in Ordu on June 13, 2016, under ecological conditions of the main crop. The study used a randomized block experimental design with three replications. The plots at the trial site were seeded with sole crops of maize and soybean, intercropped maize and soybean. Table 1 shows the patterns of seeding. Prior to seeding, soybean seeds were inoculated using Rhizobium japonicum L. bacteria supplied from the Soil, Fertilizer and Water Resources Central Research Institute. Each plot was designed to have a length of 4 meters, a width of 7.7 meters, and 12 rows of seeding $\left(30.8 \mathrm{~m}^{2}\right)$. An inter-row spacing of $70 \mathrm{~cm}$ was maintained for all row arrangements. An intra-row spacing of $20 \mathrm{~cm}$ was maintained for both the distinct row intercrops and the sole crop of maize. An intra-row spacing of $5 \mathrm{~cm}$ was maintained for both the distinct row intercrops and the sole crop of soybean.

Table 1. Row Arrangements of Intercropping

\begin{tabular}{c|c}
\hline Crop Rows & Intercropping \\
\hline Maize & Sole Crop \\
Soybean & Sole Crop \\
1 row of soybean +1 row of maize & Distinct-row \\
2 rows of soybean +1 row of maize & Distinct-row \\
3 rows of soybean +1 row of maize & Distinct-row \\
1 row of soybean +2 rows of maize & Distinct-row \\
1 row of soybean +3 rows of maize & Distinct-row \\
\hline
\end{tabular}

Fertilization was carried out on the basis of the three periods of the growing cycle of maize and soybean. Diammonium phosphate (DAP, 18.46.0) was used as the bottom fertilizer and calcium ammonium nitrate $(\mathrm{CAN}, 46 \%)$. Table 2 describes the time and amount of fertilizers applied to the plots.

Table 2. Time and Amount of Fertilizers Applied on the Plots

\begin{tabular}{c|c|c}
\hline Time of Fertilizer Application & Fertilized Plot & Amount of Fertilizer \\
\hline \multirow{2}{*}{ Pre-seeding } & $\begin{array}{c}\text { Sole Maize } \\
\text { Soybean- Maize }\end{array}$ & $\begin{array}{c}\text { Pure } 0.7 \mathrm{~kg} \mathrm{ha}^{-1} \mathrm{~N} /, \\
0.7 \mathrm{~kg} \mathrm{ha}^{-1} \mathrm{P}_{2} \mathrm{O}_{5}\end{array}$ \\
\cline { 2 - 3 } & Sole Soybean & $\begin{array}{c}\text { Pure } 0.3 \mathrm{~kg} \mathrm{ha}^{-1} \mathrm{~N} \\
0.7 \mathrm{~kg} \mathrm{ha}^{-1} \mathrm{P}_{2} \mathrm{O}_{5}\end{array}$ \\
\cline { 2 - 3 } Bolting Time & $\begin{array}{c}\text { Sole Maize } \\
\text { Soybean - Maize }\end{array}$ & Pure $0.7 \mathrm{~kg} \mathrm{ha}^{-1} \mathrm{~N}$ \\
\hline Maize Dent Stage & $\begin{array}{c}\text { Sole Maize } \\
\text { Soybean - Maize }\end{array}$ & Pure $0.7 \mathrm{~kg} \mathrm{ha}^{-1} \mathrm{~N}$ \\
\hline
\end{tabular}


Hoeing and weeding were done, when necessary, to control weeds and air the soil on all sole-cropping and intercropping plots. According to crop water needs, crops were irrigated four times using springer irrigation system: the time when crops attain a height of $20 \mathrm{~cm}$, at maize tasseling and soybean flowering stages, at pollination stage, and at maize dent and soybean seed-filling stages.

Technological and physiological measurements made in the experiment are given in Table 3.

Table 3. List of technological and physiological traits measured

\begin{tabular}{|c|c|c|}
\hline Trait & Maize & Soybean \\
\hline $\begin{array}{l}\text { Chlorophyll } \\
\text { Concentration Index }\end{array}$ & $\begin{array}{l}\text { Chlorophyll concentration index of } 10 \text { plants } \\
\text { randomly selected from each plot chlorophyll } \\
\text { concentration index was determined by } \\
\text { measuring chlorophyll in sunny and cloudy } \\
\text { days in the leaves of corn plant by using } \\
\text { Apogee tool. }\end{array}$ & $\begin{array}{l}\text { Chlorophyll concentration index of } 10 \\
\text { plants randomly selected from each plot } \\
\text { chlorophyll concentration index was } \\
\text { determined by measuring chlorophyll in } \\
\text { sunny and cloudy days in the leaves of } \\
\text { soybean plant by using Apogee tool. }\end{array}$ \\
\hline Leaf area & $\begin{array}{c}\mathrm{LA}=\left[\begin{array}{c}\left.-5.87+(2.76 \mathrm{xW})+(1.11 \mathrm{xL})+\left(0.04 \mathrm{XL}^{2}\right)\right] \\
+\left[0.05 \mathrm{x}\left(\mathrm{LxW} \mathrm{W}^{2}\right)\right]\end{array}\right. \\
\text { LA: Leaf Area, L: Leaf length, W: Leaf width }\end{array}$ & $\begin{array}{l}\text { Digimizer is determined using the package } \\
\text { program. }\end{array}$ \\
\hline Ash Content & $\begin{array}{l}\text { The grains of } 10 \text { plants were randomly harveste } \\
\text { sieve. Calculation of ash ratio calculated using } t \\
\text { Ash } \%=\frac{\text { Weight of bumt sample x } 100}{\text { Weight of unburned sample }}\end{array}$ & \\
\hline $\begin{array}{l}\text { Protein content, } \\
\text { Crude fat content }\end{array}$ & $\begin{array}{l}\text { The grains of } 10 \text { plants taken from each parcel } \\
\text { were randomly blended and identified in non- } \\
\text { grinded samples using the IC-1020WE maize } \\
\text { calibration kit in the "Near Infrared Reflection" } \\
\text { (NIRS) device. }\end{array}$ & $\begin{array}{l}\text { The grains of } 10 \text { plants were randomly } \\
\text { harvested from each plot and were } \\
\text { determined in the non-grinded samples } \\
\text { using the IC-0923FE soybean calibration } \\
\text { set in the Near Infrared Reflecting" (NIRS) } \\
\text { device. }\end{array}$ \\
\hline Fatty acids & \multicolumn{2}{|c|}{$\begin{array}{l}\text { The grains of } 10 \text { plants randomly collected from each plot were blended and the amount of } \\
\text { fatty acids was determined as \% in Gas Chromatography. }\end{array}$} \\
\hline Grain Yield & \multicolumn{2}{|c|}{$\begin{array}{l}\text { In } 10 \text { plants randomly collected from each plot, the grains are blended and the grain } \\
\text { moisture is arranged according to } 14 \% .10 \text { plant yield per hectare multiplied by the number } \\
\text { of plants and yield per hectare }\end{array}$} \\
\hline $\begin{array}{l}\text { Land Equivalent Ratio } \\
\text { (LER) }\end{array}$ & \multicolumn{2}{|c|}{$\begin{array}{l}\text { The land equivalent ratio (LER) was calculated as the sum of the relative yields of maize } \\
\text { and soybean in the intercropping plots to the monocropping plots using the following } \\
\text { equation: } \\
\text { LER }=\left[\frac{\text { Yint-soy }}{\text { Ymono-soy }}\right]+\left[\frac{\text { Ymt-maize }}{\text { Ymono-maize) }}\right] \\
\text { LER = LERsoy+LERmaize =Yint-soy +Yint-maize Ymono-soy Ymono-maize where } \\
\text { Yint-soy, Ymono-soy, Yint-maize, and Ymono-maize are the grain yields }\left(\mathrm{kg} \mathrm{ha}^{-1}\right) \text { of } \\
\text { intercropped soybean, monocropped soybean, intercropped maize, and monocropped } \\
\text { maize, respectively. }\end{array}$} \\
\hline
\end{tabular}

After crops attained full maturity, they were harvested October 25, 2016 (Fig. 2). After edges of $50 \mathrm{~cm}$ were cut to avoid edge effect during harvesting, technological properties were analyzed on 10 crops randomly selected among maize and soybeans. LER values were calculated for the seeding plots to determine the efficiency of the land use by dividing the intercrop yields of maize and soybean to the sole yields of maize and soybean and then adding two values. SAS-JMP 10.0 statistical software was used to run an analysis variance on the values based on a randomized block experimental design. The Least Significant Difference (LSD) test was used to measure significant differences between means. 


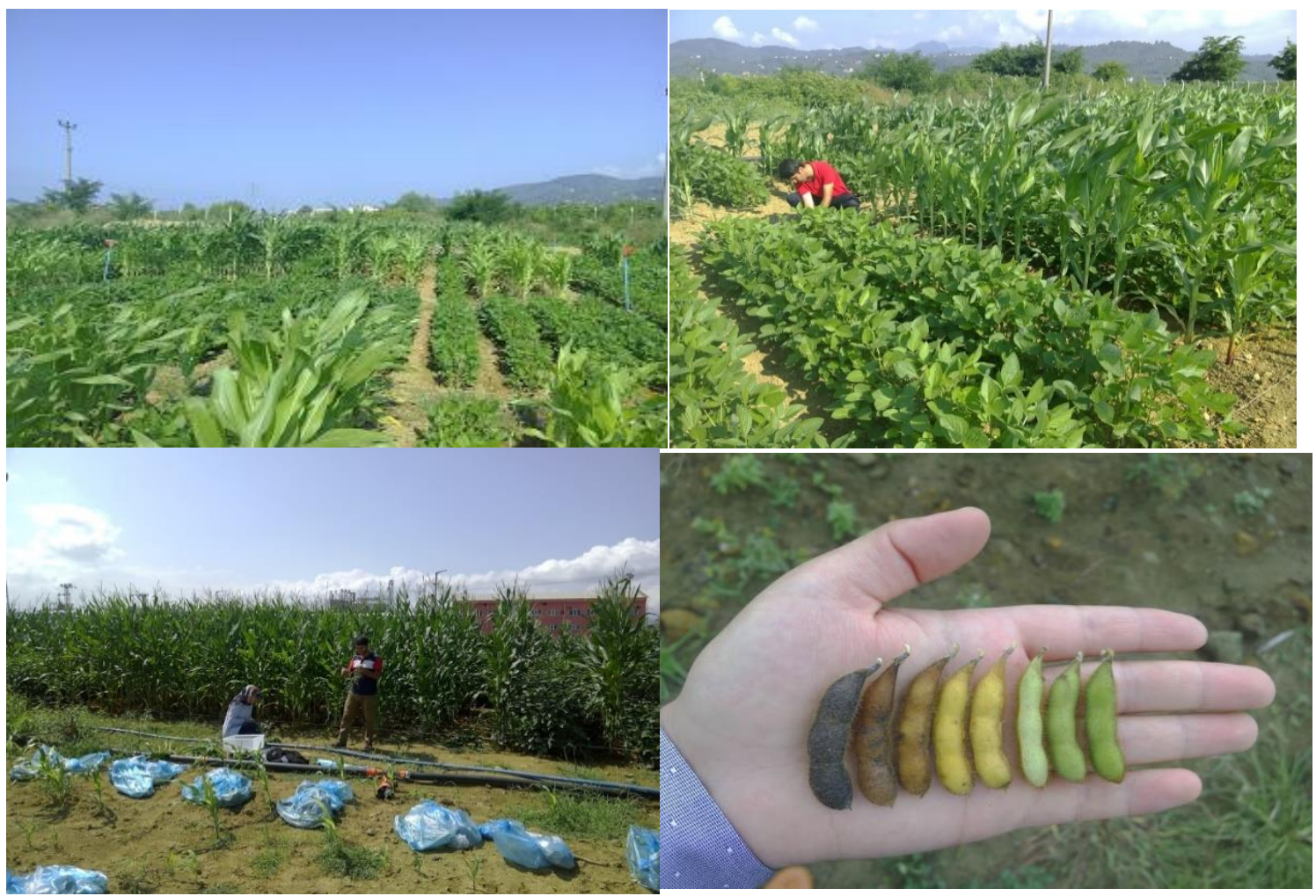

Figure 2. Some views from experimental plots

\section{Results and discussion}

\section{Chlorophyll Concentration Index (CCI) of Maize}

Considering the effect of intercropping on the chlorophyll concentration content of the maize plant, no significant difference was found. The CCI varied from 45.50 to 50.93. The lowest CCI was observed in the sole-cropped maize, while the highest CCI was observed in two rows of soybean intercropped with one row of maize. The mean CCI of the intercropped maize was found to be 47.91 (Table 4).

Our results on the maize chlorophyll concentration index are reported $35.17-47.03$ in Choudrary et al. (2014), 17.89 - 29.53 in Sabanc1 (2015).

Table 4. The Values of CCI, Leaf Area, Ash Content, Protein Content, and Crude Fat Content for the Intercropped Maize

\begin{tabular}{cccccc}
\hline Intercropping & CCI & Leaf Area $\left(\mathbf{c m}^{2}\right)$ & Ash Content (\%) & Protein Content (\%) & $\begin{array}{c}\text { Crude Fat } \\
\text { Content }(\%)\end{array}$ \\
\hline SM & 45.50 & 436.58 & $7.02 \mathrm{bc}$ & 9.26 & 3.90 \\
$1 \mathrm{~S}+1 \mathrm{M}$ & 48.23 & 430.27 & $5.76 \mathrm{c}$ & 10.11 & 3.93 \\
$1 \mathrm{~S}+2 \mathrm{M}$ & 46.56 & 360.51 & $8.05 \mathrm{ab}$ & 10.03 & 3.35 \\
$1 \mathrm{~S}+3 \mathrm{M}$ & 46.23 & 384.56 & $8.86 \mathrm{a}$ & 10.54 & 4.85 \\
$2 \mathrm{~S}+1 \mathrm{M}$ & 50.93 & 476.39 & $9.30 \mathrm{a}$ & 10.77 & 4.15 \\
$3 \mathrm{~S}+1 \mathrm{M}$ & 50.06 & 510.19 & $8.78 \mathrm{ab}$ & 10.51 & 3.53 \\
\hline Mean & 47.91 & 433.08 & 7.96 & 10.20 & 3.95 \\
\hline Significance & - & - & - & - & - \\
\hline LSD & - & - & 1.88 & - & - \\
\hline
\end{tabular}

CCI: Chlorophyll Content Index, SM: Sole Maize, S: Soybean, and M: Maize 


\section{CCI of Soybean}

Considering the effect of intercropping on the chlorophyll concentration content of the soybean plant, no significant difference was found. The CCI varied from 42.33 to 44.43. The lowest CCI was observed in the sole-cropped soybean, while the highest CCI was observed in three rows of soybeans intercropped with one row of maize. The mean CCI of the intercropped soybean was 43.30 (Table 5).

Sole cropping of corn had the least chlorophyll content, while in all intercropping treatments especially when corn was in neighboring of soybean, chlorophyll content of corn significantly increased (Amini et al., 2013).

Table 5. The Values of CCI, Leaf Area, Ash Content, Protein Content, and Crude Fat Content for the Intercropped Soybean

\begin{tabular}{cccccc}
\hline Intercropping & CCI & Leaf Area $\left(\mathbf{c m}^{2}\right)$ & Ash Content (\%) & Protein Content (\%) & $\begin{array}{c}\text { Crude Fat } \\
\text { Content }(\%)\end{array}$ \\
\hline SS & 42.33 & 32.41 & 9.82 & $43.56 \mathrm{bc}$ & $20.20 \mathrm{~b}$ \\
$1 \mathrm{~S}+1 \mathrm{M}$ & 43.20 & 39.50 & 10.82 & $45.38 \mathrm{a}$ & $19.65 \mathrm{~b}$ \\
$1 \mathrm{~S}+2 \mathrm{M}$ & 42.53 & 32.72 & 10.74 & $44.70 \mathrm{ab}$ & $20.06 \mathrm{~b}$ \\
$1 \mathrm{~S}+3 \mathrm{M}$ & 44.13 & 39.96 & 10.72 & $44.62 \mathrm{ab}$ & $20.00 \mathrm{~b}$ \\
$2 \mathrm{~S}+1 \mathrm{M}$ & 43.23 & 41.38 & 10.44 & $44.34 \mathrm{ab}$ & $19.93 \mathrm{~b}$ \\
$3 \mathrm{~S}+1 \mathrm{M}$ & 44.43 & 37.01 & 9.67 & $42.92 \mathrm{c}$ & $20.77 \mathrm{a}$ \\
\hline Mean & 43.30 & 37.16 & 10.36 & 44.08 & 20.10 \\
\hline Significance & - & - & - & $*$ & $*$ \\
\hline LSD & - & - & - & 1.35 & 0.56 \\
\hline
\end{tabular}

CCI: Chlorophyll Content Index, SM: Sole Soybean, S: Soybean, and M: Maize

\section{Maize Leaf Area $\left(\mathrm{cm}^{2}\right)$}

Considering the effect of intercropping on the leaf area of the maize plant, no significant difference was found. The leaf area of maize varied from $360.51 \mathrm{~cm}^{2}$ to $510.19 \mathrm{~cm}^{2}$. The smallest leaf area was observed in one row of soybean intercropped with two rows of maize, while the largest leaf area was observed in three rows of soybean intercropped with one row of maize. The mean leaf area of the intercropped maize was $433.08 \mathrm{~cm}^{2}$ (Table 4).

Our results on the maize leaf area are above those reported to be $305.96-325.62 \mathrm{~cm}^{2}$ in Subedi and Ma (2005) but below those reported to be $877.3-626 \mathrm{~cm}^{2}$ in $\mathrm{He}$ et al. (2011). A positive significant relationship has been reported between the number of leaves per plant and the leaf area of maize (Öner et al., 2012).

\section{Soybean Leaf Area $\left(\mathrm{cm}^{2}\right)$}

Considering the effect of intercropping on the leaf area of the soybean plant, no significant difference was found. The leaf area of soybean varied from $32.41 \mathrm{~cm}^{2}$ to $41.38 \mathrm{~cm}^{2}$. The smallest leaf area was observed in the sole-cropped soybean, while the largest leaf area was observed in two rows of soybean intercropped with one row of maize. The mean leaf area of the intercropped soybean was $37.16 \mathrm{~cm}^{2}$ (Table 5).

Our results on the soybean leaf area are below those reported to be $68.70-35.50 \mathrm{~cm}^{2}$ in Ngalamu et al. (2012). 


\section{Maize Ash Content (\%)}

The effect of intercropping on the ash content of the maize plant was found to be statistically significant $(\mathrm{P}<0.05)$. The ash content of maize varied from 5.76 to $9.30 \%$. The lowest ash content was observed in one row of soybean intercropped with one row of maize, while the highest ash content was observed in two rows of soybean intercropped with one row of maize. The mean ash content of the intercropped maize was $7.96 \%$ (Table 4).

Our results on the maize ash content are above those reported to be $1.46-1.81 \%$ in Lucchin et al. (2003), and those reported to be $1.08-2.22 \%$ in Moreno et al. (2015).

\section{Soybean Ash Content (\%)}

The effect of intercropping on the ash content of the soybean plant was statistically insignificant. The ash content of soybean varied from 9.67 to $10.82 \%$. The lowest ash content was observed in three rows of soybean intercropped with one row of maize, while the highest ash content was observed in one row of soybean intercropped with one row of maize. The mean ash content of the intercropped soybean was $10.36 \%$ (Table 5). Our results on the maize ash content are above those reported to be 1.99 $18.74 \%$ in Ahmad et al. (2016).

\section{Maize Protein Content (\%)}

The effect of intercropping on the protein content of the maize plant was statistically insignificant. The protein content of maize varied from 9.26 to $10.77 \%$. The lowest protein content was observed in the sole-cropped maize, while the highest protein content was observed in two rows of soybean intercropped with one rows of maize. The mean protein content of the intercropped maize was $10.20 \%$ (Table 4).

Our results on the maize protein content are consistent with those reported to be 7.94 - 10.61\% in Bekele and Rao (2014), while they are below those reported to be 11.02 $12.73 \%$ in Öner et al. (2011) but above those reported to be $6.21-8.65 \%$ in Vartanl and Emeklier (2007).

\section{Soybean Protein Content (\%)}

The effect of intercropping on the protein content of the soybean plant was statistically significant $(\mathrm{P}<0.05)$. The protein content of soybean varied from 42.92 to $45.38 \%$. The lowest protein content was observed in three rows of soybean intercropped with one row of maize, while the highest protein content was observed in one row of soybean intercropped with one row of maize. The mean protein content of the intercropped soybean was $44.08 \%$ (Table 5).

Our results on the soybean protein content are consistent with those reported to be $44.30-47.20 \%$ in Şenyiğit et al. (2015), while they are above those reported to be 32.27 - 33.87\% in Aydemir and Kızılşimşek (2018).

\section{Maize Crude Fat Content (\%)}

Considering the effect of intercropping on the crude fat content of the maize plant, no significant difference was found. The crude fat content of maize varied from 3.35 to $4.85 \%$. The lowest crude fat content was observed in one row of soybean intercropped with two rows of maize, while the highest crude fat content was observed in one row of 
soybean intercropped with three rows of maize. The mean crude fat content of the intercropped maize was $3.95 \%$ (Table 4).

Our results on the maize crude fat content are consistent with those reported to be $3.50-8.30 \%$ in Hartings et al. (2008), while they are below those reported to be 11 $6.28 \%$ in Akınc1 et al. (2011) but above those reported to be $2.71-3.24 \%$ in Sabanc1 (2016).

\section{Soybean Crude Fat Content (\%)}

The effect of intercropping on the crude fat content of the soybean plant was statistically significant $(\mathrm{P}<0.05)$. The crude fat content of soybean varied from 19.65 to $20.77 \%$. The lowest crude fat content was observed in one row of soybean intercropped with one row of maize, while the highest crude fat content was observed in three rows of soybean intercropped with one row of maize. The mean crude fat content of the intercropped soybean was $20.10 \%$ (Table 5).

Our results on the soybean crude fat content are consistent with those reported to be $17.54-19.90 \%$ in Kan et al. (2011), while they are below those reported to be 22.06 $24.67 \%$ in Dolapçı (2012) but above those reported to be $12.00-14.00 \%$ in Karagül et al. ( 2011).

\section{Maize Palmitic Acid Content (\%)}

Palmitic acid is the second most common saturated fatty acids, following oleic acid. Palmitic acid composes 15 - 50\% of fatty acids found in most fats (Kale et al., 2017). The effect of intercropping on the palmitic acid content of the maize plant was statistically insignificant. The palmitic acid content of maize varied 12.17 to $13.12 \%$. The lowest palmitic acid content was observed in one row of soybean intercropped with three rows of maize, while the highest palmitic acid content was observed in the solecropped maize. The mean palmitic acid content of the intercropped maize was $12.45 \%$ (Table 6).

Our results on the maize palmitic acid content are consistent with those reported to be $12.79-15.55 \%$ in Akinc1 et al. (2011), while they are above that reported to be $11.20 \%$ in Kan et al. (2011).

Table 6. The Values of Palmitic Acid (\%), Stearic Acid (\%), Oleic Acid (\%), Linoleic Acid (\%) and Linolenic Acid (\%) for the Intercropped

\begin{tabular}{cccccc}
\hline Intercropping & $\begin{array}{c}\text { Palmitic Acid } \\
(\boldsymbol{\%})\end{array}$ & $\begin{array}{c}\text { Stearic Acid } \\
(\boldsymbol{\%})\end{array}$ & $\begin{array}{c}\text { Oleic Acid } \\
(\boldsymbol{\%})\end{array}$ & $\begin{array}{c}\text { Linoleic Acid } \\
(\boldsymbol{\%})\end{array}$ & $\begin{array}{c}\text { Linolenic Acid } \\
(\boldsymbol{\%})\end{array}$ \\
\hline SM & 13.12 & 2.25 & 24.51 & 58.97 & 1.13 \\
$1 \mathrm{~S}+1 \mathrm{M}$ & 12.44 & 2.44 & 24.54 & 59.63 & 0.91 \\
$1 \mathrm{~S}+2 \mathrm{M}$ & 12.46 & 2.08 & 24.94 & 59.43 & 1.06 \\
$1 \mathrm{~S}+3 \mathrm{M}$ & 12.17 & 1.98 & 23.86 & 60.90 & 1.06 \\
$2 \mathrm{~S}+1 \mathrm{M}$ & 12.29 & 1.99 & 24.95 & 59.80 & 0.93 \\
$3 \mathrm{~S}+1 \mathrm{M}$ & 12.25 & 2.19 & 24.91 & 59.63 & 1.00 \\
\hline Mean & 12.45 & 2.15 & 24.61 & 59.72 & 1.01 \\
\hline Significance & - & - & - & - & - \\
\hline LSD & - & - & - & - & - \\
\hline
\end{tabular}

SM: Sole Soybean, S: Soybean, and M: Maize 


\section{Maize Stearic Acid Content (\%)}

The effect of intercropping on the stearic acid content of the maize plant was also statistically insignificant. The stearic acid content of maize varied from 1.98 to $2.44 \%$. The lowest stearic acid content was observed in one row of soybean intercropped with three rows of maize, while the highest stearic acid content was observed in one row of soybean intercropped with one row of maize. The mean stearic acid content of the intercropped maize was $2.15 \%$ (Table 6).

Our results on the maize stearic acid content are consistent with that reported to be $1.88-2.13 \%$ in Kaplan et al. (2017), while they are below those reported to be 2.87 $3.50 \%$ in Akınc1 et al. (2011).

\section{Maize Oleic Acid Content (\%)}

Oleic acid is the most common fatty acid in nature. More than half of the fatty acids in most fats is oleic acid. It is quite rare that oils have less than $10 \%$ oleic acid. All natural oils and phospholipids known to date have oleic acid (Kaplan et al., 2017).

The effect of intercropping on the oleic acid content of the maize plant was also statistically insignificant. The oleic acid content of maize varied from 23.86 to $24.95 \%$. The lowest oleic acid content was observed in one row of soybean intercropped with three rows of maize, while the highest oleic acid content was observed in two rows of soybean intercropped with one row of maize. The mean oleic acid content of the intercropped maize was $24.61 \%$ (Table 6).

Our results on the maize oleic acid content are consistent with that reported to be $24 \%$ in Lambert (2000), while they are below that reported to be $20-50 \%$ in Olmos et al. (2018).

\section{Maize Linoleic Acid Content (\%)}

The effect of intercropping on the linoleic acid content of the maize plant was also statistically insignificant. The linoleic acid content of maize varied from 58.97 to $60.90 \%$. The lowest linoleic acid content was observed in the sole-cropped maize, while the highest linoleic acid content was observed in one row of soybean intercropped with three rows of maize. The mean linoleic acid content of the intercropped maize was $59.72 \%$ (Table 6).

Our results on the maize linoleic acid content are above those reported to be 41.84 $50.70 \%$ in Betancourt et al. (2017).

\section{Maize Linolenic Acid Content (\%)}

The effect of intercropping on the linolenic acid content of the maize plant was also statistically insignificant. The linolenic acid content of maize varied from 0.91 to $1.13 \%$. The lowest linolenic acid content was observed in one row of soybean intercropped with one row of maize, while the highest linolenic acid content was observed in the sole-cropped maize. The mean linolenic acid content of the intercropped maize was $1.01 \%$ (Table 6).

Our results on the maize linolenic acid content are consistent with that reported to be $0.65-0.95 \%$ in Betancourt et al. (2017), while they are below those reported to be 1.31 $2.02 \%$ in Akınc1 et al. (2011). 


\section{Maize Unsaturated Fatty Acid Content (\%)}

Unsaturated fatty acids have double bonds (Ramos et al., 2009). The effect of intercropping on the unsaturated fatty acid content of the maize plant was also statistically insignificant. The unsaturated fatty acid content of maize varied from 84.62 to $85.84 \%$. The lowest unsaturated fatty acid content was observed in the sole-cropped maize, while the highest unsaturated fatty acid content was observed in one row of soybean intercropped with three rows of maize. The mean unsaturated fatty acid content of the intercropped maize was $85.37 \%$ (Table 7).

\section{Maize Saturated Fatty Acid Content (\%)}

Saturated fatty acids have no double (Ramos et al., 2009). The effect of intercropping on the saturated fatty acid content of the maize plant was also statistically insignificant. The saturated fatty acid content of maize varied from 14.15 to $15.37 \%$. The lowest saturated fatty acid content was observed in one row of soybean intercropped with three rows of maize, while the highest saturated fatty acid content was observed in the solecropped soybean. The mean saturated fatty acid content of the intercropped maize was $14.61 \%$ (Table 7).

Table 7. The Values of Unsaturated Fat Acid Content, Saturated Fat Acid Content, and Unsaturated to Saturated Fat Acid Ratio for the Intercropped Maize

\begin{tabular}{cccc}
\hline Intercropping & $\begin{array}{c}\text { Unsaturated Fat Acid } \\
\text { Content }(\boldsymbol{\%})\end{array}$ & $\begin{array}{c}\text { Saturated Fat Acid } \\
\text { Content }(\boldsymbol{\%}) * *\end{array}$ & $\begin{array}{c}\text { Unsaturated to Saturated Fat } \\
\text { Acid Ratio (\%) }\end{array}$ \\
\hline SM & 84.62 & 15.37 & 5.50 \\
$1 \mathrm{~S}+1 \mathrm{M}$ & 85.10 & 14.89 & 5.72 \\
$1 \mathrm{~S}+2 \mathrm{M}$ & 85.44 & 14.55 & 5.87 \\
$1 \mathrm{~S}+3 \mathrm{M}$ & 85.84 & 14.15 & 6.08 \\
$2 \mathrm{~S}+1 \mathrm{M}$ & 85.70 & 14.29 & 5.99 \\
$3 \mathrm{~S}+1 \mathrm{M}$ & 85.55 & 14.44 & 5.92 \\
\hline Mean & 85.37 & 14.61 & 5.84 \\
\hline Significance & - & - & - \\
\hline LSD & - & - & - \\
\hline
\end{tabular}

* Unsaturated fat acid content $(\%)=$ oleic acid + linoleic acid + linolenic acid

$*$ * Saturated fat acid content $(\%)=$ palmitic acid + stearic acid

\section{Maize Unsaturated to Saturated Fatty Acid Ratio (\%)}

The most important property that determines the quality of vegetable fats is the ratio of the total amount of unsaturated fatty acids to the total amount of saturated fatty acids. The effect of intercropping on the unsaturated to saturated fatty acid ratio of the maize plant was also statistically insignificant. The unsaturated to saturated fatty acid ratio of maize varied from 5.50 to $6.08 \%$. The lowest ratio was observed in the sole-cropped maize, while the highest ratio was observed in one row of soybean intercropped with three rows of maize. The mean unsaturated to saturated fatty acid ratio of the intercropped maize was $5.84 \%$ (Table 7 ).

\section{Soybean Palmitic Acid Content (\%)}

The effect of intercropping on the palmitic acid content of the soybean plant was statistically insignificant. The palmitic acid content of soybean varied 10.39 to $10.77 \%$. The lowest palmitic acid content was observed in one row of soybean intercropped with 
two rows of maize, while the highest palmitic acid content was observed in the solecropped maize and in one row of soybean intercropped with one row of maize. The mean palmitic acid content of the intercropped soybean was $10.64 \%$ (Table 8).

Our results on the soybean palmitic acid content are consistent with those reported to be 2.7 - 11.2\% in Bilyeu et al. (2018), while they are below those reported to be 10.98 $12.88 \%$ in Arığlu et al. (2012) but above those reported to be $8.80-10.30 \%$ in Arıoglu et al. (2012).

\section{Soybean Stearic Acid Content (\%)}

The effect of intercropping on the stearic acid content of the soybean plant was also statistically insignificant. The stearic acid content of soybean varied from 3.81 to $4.28 \%$. The lowest stearic acid content was observed in the sole-cropped soybean, while the highest stearic acid content was observed in three rows of soybean intercropped with one row of maize. The mean stearic acid content of the intercropped soybean was 3.99 $\%$ (Table 8).

Our results on the soybean stearic acid content are consistent with those reported to be $3.60-4.70 \%$ in Kan et al. (2011), while they are below those reported to be 4 $12.1 \%$ in Carrero et al. (2014) but above those reported to be $1.15-2.02 \%$ in Sultan et al. (2015).

Table 8. The Values of Palmitic Acid, Stearic Acid, Oleic Acid, Linoleic Acid, and Linolenic Acid for the Intercropped Soybean

\begin{tabular}{|c|c|c|c|c|c|}
\hline Intercropping & Stearic Acid (\%) & Palmitic Acid (\%) & Oleic Acid (\%) & Linoleic Acid (\%) & Linolenic Acid (\%) \\
\hline SS & 3.81 & 10.77 & 20.06 & 58.26 & 7.07 \\
\hline $1 \mathrm{~S}+1 \mathrm{M}$ & 3.99 & 10.77 & 19.86 & 58.59 & 6.78 \\
\hline $1 \mathrm{~S}+2 \mathrm{M}$ & 4.06 & 10.39 & 19.88 & 58.59 & 7.05 \\
\hline $1 S+3 M$ & 3.84 & 10.76 & 19.87 & 58.61 & 6.91 \\
\hline $2 S+1 M$ & 3.97 & 10.48 & 19.97 & 58.98 & 6.58 \\
\hline $3 \mathrm{~S}+1 \mathrm{M}$ & 4.28 & 10.71 & 20.29 & 58.01 & 6.61 \\
\hline Mean & 3.99 & 10.64 & 19.98 & 58.50 & 6.83 \\
\hline Significance & - & - & - & - & - \\
\hline LSD & - & - & - & - & - \\
\hline
\end{tabular}

\section{Soybean Oleic Acid Content (\%)}

The effect of intercropping on the oleic acid content of the soybean plant was also statistically insignificant. The oleic acid content of soybean varied from 19.86 to $20.29 \%$. The lowest oleic acid content was observed in one row of soybean intercropped with one row of maize, while the highest oleic acid content was observed in three rows of soybean intercropped with one row of maize. The mean oleic acid content of the intercropped soybean was $19.98 \%$ (Table 8 ).

Our results on the maize oleic acid content are consistent with that reported to be $20.09-20.88 \%$ in Sultan et al. (2015), while they are below those reported to be 22.20 $25.90 \%$ in Kan (2011).

\section{Soybean Linoleic Acid Content (\%)}

The effect of intercropping on the linoleic acid content of the soybean plant was also statistically insignificant. The linoleic acid content of soybean varied from 58.01 to 
$58.98 \%$. The lowest linoleic acid content was observed in three rows of soybean intercropped with one row of maize, while the highest linoleic acid content was observed in two rows of soybean intercropped with one row of maize. The mean linoleic acid content of the intercropped soybean was $58.50 \%$ (Table 8).

Our results on the maize linoleic acid content are below those reported to be 50.30 $54.30 \%$ in Kan (2011).

\section{Soybean Linolenic Acid Content (\%)}

The effect of intercropping on the linolenic acid content of the soybean plant was also statistically insignificant. The linolenic acid content of soybean varied from 6.58 to $7.07 \%$. The lowest linolenic acid content was observed in two rows of soybean intercropped with one row of maize, while the highest linolenic acid content was observed in the sole-cropped soybean. The mean linolenic acid content of the intercropped soybean was $6.83 \%$ (Table 8 ).

Our results on the soybean linolenic acid content are consistent with those reported to be $6.30-7.62 \%$ in Arığlu et al. (2012), while they are below those reported to be 7 $10 \%$ in Kim et al. (2015).

\section{Soybean Unsaturated Fatty Acid Content (\%)}

The effect of intercropping on the unsaturated fatty acid content of the soybean plant was also statistically insignificant. The unsaturated fatty acid content of soybean varied from 84.92 to $85.54 \%$. The lowest unsaturated fatty acid content was observed three rows of soybean intercropped with one row of maize, while the highest unsaturated fatty acid content was observed in two rows of soybean intercropped with one rows of maize. The mean unsaturated fatty acid content of the intercropped soybean was $85.33 \%$ (Table 9).

Our results on the soybean unsaturated fatty acid content are consistent with those reported to be $82.02-84.93 \%$ in Arığlu et al. (2012), while they are below those reported to be $88.12-88.58 \%$ in Sultan et al. (2015).

\section{Soybean Saturated Fatty Acid Content (\%)}

The effect of intercropping on the saturated fatty acid content of the soybean plant was also statistically insignificant. The saturated fatty acid content of soybean varied from 14.45 to $14.99 \%$. The lowest saturated fatty acid content was observed in two rows of soybean intercropped with one row of maize, while the highest saturated fatty acid content was observed in three rows of soybean intercropped with one row of maize. The mean saturated fatty acid content of the intercropped soybean was $14.64 \%$ (Table 9).

Our results on the soybean saturated fatty acid content are consistent with those reported to be $13.59-16.88 \%$ in Arığlu et al. (2012), while they are below those reported to be 17.60 - 20.36\% in Barış (2016) but above those reported to be 11.42 $11.80 \%$ in Sultan et al. (2015).

\section{Soybean Unsaturated to Saturated Fatty Acid Ratio (\%)}

The effect of intercropping on the unsaturated to saturated fatty acid ratio of the soybean plant was also statistically insignificant. The unsaturated to saturated fatty acid ratio of soybean varied from 5.66 to $5.91 \%$. The lowest ratio was observed in three rows of soybean intercropped with one row of maize, while the highest ratio was observed in 
one row of soybean intercropped with two rows of maize. The mean unsaturated to saturated fatty acid ratio of the intercropped soybean was $5.83 \%$ (Table 9).

Our results on the soybean unsaturated fatty acid content are consistent with those reported to be $6.25-4.90 \%$ in Arığlu et al. (2012), while they are above those reported to be $3.92-4.69 \%$ in Barıș (2016).

Table 9. The Values of Unsaturated Fat Acid Content, Saturated Fat Acid Content, and Unsaturated to Saturated Fat Acid Ratio for the Intercropped Soybean

\begin{tabular}{cccc}
\hline Intercropping & $\begin{array}{c}\text { Unsaturated Fat } \\
\text { Acid Content (\%)* }\end{array}$ & $\begin{array}{c}\text { Saturated Fat } \\
\text { Acid Content (\%) ** }\end{array}$ & $\begin{array}{c}\text { Unsaturated to Saturated } \\
\text { Fat Acid Ratio (\%) }\end{array}$ \\
\hline SS & 85.40 & 14.59 & 5.86 \\
$1 \mathrm{~S}+1 \mathrm{M}$ & 85.23 & 14.76 & 5.79 \\
$1 \mathrm{~S}+2 \mathrm{M}$ & 85.53 & 14.46 & 5.91 \\
$1 \mathrm{~S}+3 \mathrm{M}$ & 85.39 & 14.60 & 5.85 \\
$2 \mathrm{~S}+1 \mathrm{M}$ & 85.54 & 14.45 & 5.93 \\
$3 \mathrm{~S}+1 \mathrm{M}$ & 84.92 & 14.99 & 5.66 \\
\hline Mean & 85.33 & 14.64 & 5.83 \\
\hline Significance & - & - & - \\
\hline LSD & - & - & - \\
\hline
\end{tabular}

* Unsaturated fat acid content $(\%)=$ oleic acid + linoleic acid + linolenic acid

$*$ * Saturated fat acid content $(\%)=$ palmitic acid + stearic acid

\section{Maize Grain Yield $\left(\mathrm{kg} \mathrm{ha}^{-1}\right)$}

The effect of intercropping on the grain yield of the maize plant was found to be statistically very significant $(\mathrm{P}<0.01)$. The grain yield of maize varied from $32.01 \mathrm{~kg} \mathrm{ha}^{-}$ ${ }^{1}$ to $89.52 \mathrm{~kg} \mathrm{ha}^{-1}$. The lowest grain yield was observed in three rows of soybean intercropped with one row of maize, while the highest grain yield was observed in the sole-cropped maize. The mean grain yield of the intercropped maize was $63.20 \mathrm{~kg} \mathrm{ha}^{-1}$ (Table 10).

Our results on the maize grain yield are consistent with those reported to be 37.00 $51.00 \mathrm{~kg} \mathrm{ha}^{-1}$ in Ijoyah and Fanen (2012) and $67.50 \mathrm{~kg} \mathrm{ha}^{-1}$ in All et al. (2015), while they are above that reported to be $17.70 \mathrm{~kg} \mathrm{ha}^{-1}$ in Raj1 (2007).

\section{Soybean Grain Yield (kg ha-1)}

The effect of intercropping on the grain yield of the soybean plant was also found to be statistically very significant $(\mathrm{P}<0.01)$. The grain yield of soybean varied from 10.36 $\mathrm{kg} \mathrm{ha}^{-1}$ to $61.11 \mathrm{~kg} \mathrm{ha}^{-1}$. The lowest grain yield was observed in one row of soybean intercropped with two rows of maize, while the highest grain yield was observed in the sole-cropped soybean. The mean grain yield of the intercropped soybean was $33.59 \mathrm{~kg}$ ha $^{-1}$ (Table 10).

Our results on the soybean grain yield are consistent with those reported to be 10.20 $\mathrm{kg} \mathrm{ha}^{-1}$ in Adeniyan and Ayoola (2007), $10.2 \mathrm{~kg} \mathrm{ha}^{-1}$ in Raji (2007), 7.80 - $12.10 \mathrm{~kg} \mathrm{ha}^{-1}$ in Ijoyah and Fanen (2012), and $10.88 \mathrm{~kg} \mathrm{ha}^{-1}$ in Ali et al. (2015).

\section{Land Equivalent Ratio (LER)}

LER refers to the land amount needed by sole-cropping to produce the equivalent yield obtained from intercropped maize and soybean. The LER value varied from 1.03 to 1.21. The highest LER was observed in three rows of soybean intercropped with one 
row of maize, while the lowest LER was observed in one row of soybean intercropped with two rows of maize (Table 10).

Our results on the LER value are consistent with those reported to be 1.27 in Wekesa et al. (2015) and 1.27 in Zhang et al. (2015), while they are below those reported to be 1.30 in Jamkhanh et al. (2012), 1.29 in Osang et al. (2014), and 1.44 in Al1 et al. (2015).

Table 10. The Values of Grain Yield and LER for the Intercropped Maize and Soybean

\begin{tabular}{cccc}
\hline Intercropping & $\begin{array}{c}\text { Maize Grain Yield } \\
\left(\mathbf{k g ~ h a}^{-\mathbf{1}}\right)\end{array}$ & $\begin{array}{c}\text { Soybean Grain Yield } \\
\left(\mathbf{k g ~ h a}^{-\mathbf{~}}\right)\end{array}$ & LER \\
\hline YM / YS & $89.52 \mathrm{a}$ & $61.11 \mathrm{a}$ & - \\
$1 \mathrm{~S}+1 \mathrm{M}$ & $59.33 \mathrm{c}$ & $27.16 \mathrm{c}$ & 1.11 \\
$1 \mathrm{~S}+2 \mathrm{M}$ & $76.53 \mathrm{~b}$ & $10.36 \mathrm{~d}$ & 1.03 \\
$1 \mathrm{~S}+3 \mathrm{M}$ & $75.71 \mathrm{~b}$ & $17.79 \mathrm{~d}$ & 1.14 \\
$2 \mathrm{~S}+1 \mathrm{M}$ & $46.07 \mathrm{~d}$ & $33.35 \mathrm{c}$ & 1.06 \\
$3 \mathrm{~S}+1 \mathrm{M}$ & $32.01 \mathrm{e}$ & $51.75 \mathrm{~b}$ & 1.21 \\
\hline Mean & 63.20 & 33.59 & - \\
\hline Significance & $* *$ & $* *$ & - \\
\hline LSD & 6.249 & 80.32 & - \\
\hline
\end{tabular}

\section{Conclusions and Suggestions}

The study has found significant differences between the applied cropping systems in terms of the maize ash content, soybean protein content, and soybean crude fat content but not in terms of the grain yields of maize and soybean. Considering the analysis results and LER values together, three rows of soybean intercropped with one row of maize were found to be the most appropriate intercropping system. However, this study needs to be carried out for 1 to 2 years for a more precise recommendation. In line with the findings of the study, further work could assess different systems of cropping and focus on the fodder and silage capacity of intercropped maize and soybean rather than grain yield.

\section{REFERENCES}

[1] Abbasi, T., Abbasi, S. (2010): Biomass energy and the environmental impacts associated with its production and utilization. - Renewable and sustainable energy reviews 14(3): 919-937.

[2] Acar, Z., Aşcı, Ö. Ö., Ayan, İ., Mut, H., Başaran, U. (2006): Yem bitkilerinde karışık ekim sistemleri. - Ondokuzmayıs Üniversitesi Ziraat Fakültesi Dergisi 21(3): 379-386.

[3] Adeniyan, O., Ayoola, O. (2007): Evaluation of four improved soybean varieties under different planting date in relayed cropping system with maize under soybean/maize/cassava intercrop. - African Journal of Biotechnology 6(19).

[4] Ahmad, M., Ok, Y. S., Rajapaksha, A. U., Lim, J. E., Kim, B.-Y., Ahn, J.-H., Lee, S. S. (2016): Lead and copper immobilization in a shooting range soil using soybean stoverand pine needle-derived biochars: Chemical, microbial and spectroscopic assessments. Journal of Hazardous Materials 301: 179-186.

[5] Akıncı, C., Karaaslan, D., Türkoğlu, H., Yıldırım, M. (2011): Bazı Mısır Çeşitlerinin Diyarbakır Şartlarındaki Yağ Asitleri Kompozisyonunun Belirlenmesi. - 9th Tarla Bitkileri Kongresi 1: 459-462. 
[6] Ali, A., Ijoyah, M., Usman, M. (2015): Intercropped maize and soybean under tillage practices and fertilizer rates in Makurdi, Southern Guinea Savanna Zone of Nigeria. International Journal of Novel Research in Civil Structral and Earth Sciences 2(2): 12-22.

[7] Amini, R., Shamayeli, M., Mohammadinasab, A. D., Ghanepour, S., Alavi-Kia, S. (2013): Relative yield total of two-and three-species intercropping of soybean, maize and sunflower. - International Journal of Agriculture and Crop Sciences 5(11): 1260.

[8] Arığlu, H., Özyurtseven, S., Güllüoğlu, L. (2012): İkinci ürün koşullarında yetiştirilen bazı soya [Glycine max (L.) Merr] çeşitlerinin yağ verimi ile yağ asitleri içeriklerinin belirlenmesi-II. - Çukurova Üniversitesi Ziraat Fakültesi Dergisi 27(2): 1-10.

[9] Aydemir, S. K., Kızılşimşek, M. (2018): Assessing yield and feed quality of intercropped sorghum and soybean in different planting patterns and in different ecologies. International Journal of Environmental Science and Technology 1-6.

[10] Barış, M. (2016): Diyarbakır Ekolojik Koşullarında Farklı Ekim Zamanı Uygulamalarının Bazı Soya Fasulyesi (Glycine max. (L.) Merrill) Çeşitlerinin Verim ve Kalite Özelliklerinin Belirlenmesi. - (Master)-Yüzüncü Y1l University, Van.

[11] Bekele, A., Rao, T. N. (2014): Estimates of heritability, genetic advance and correlation study for yield and it's attributes in maize (Zea mays L.). - Journal of Plant Sciences 2(1): 1-4.

[12] Betancourt, S. D. P., Tolentino, R. G., Schettino, B. (2017): Proximate Composition, Fatty Acid Profile and Mycotoxin Contamination in Several Varieties of Mexican Maize. - Food and Nutrition Sciences 8(09): 861.

[13] Bilyeu, K., Škrabišová, M., Allen, D., Rajcan, I., Palmquist, D. E., Gillen, A., Jo, H. (2018): The interaction of the soybean seed high oleic acid oil trait with other fatty acid modifications. - Journal of the American Oil Chemists' Society 95(1): 39-49.

[14] Carrero-Colón, M., Abshire, N., Sweeney, D., Gaskin, E., Hudson, K. (2014): Mutations in SACPD-C result in a range of elevated stearic acid concentration in soybean seed. PloS one 9(5):97891.

[15] Choudhary, S. K., Singh, R. N., Upadhyay, P. K., Singh, R. K., Choudhary, H. R., Pal, V. (2014): Effect of Vegetable Intercrops and Planting Pattern of Maize on Growth, Yield and Economics of Winter Maize (Zea mays L.) in Eastern Uttar Pradesh. - Environment \& Ecology 32(1): 101-105.

[16] Cole, C. B., Erdahl, B. S. (2018): Soybean cultivar. - CL1564482: Google Patents.

[17] Dolapçı, F. (2012): Kahramanmaraş Koşullarında Bazı Soya (Glycine max L. (Merill) Çeşitlerinin Verim ve Verim Unsurlarının Belirlenmesi. - Unpublished master's thesis.

[18] Endres, J. G. (2001): Soy protein products: characteristics, nutritional aspects, and utilization. - AOCS Publishing.

[19] Gençtan, T., Emeklier, Y., Çölkesen, M. İ. B. (1995): Sıcak İklim Tahılların Tüketim Projeksiyonları ve Üretim Hedefleri.

[20] Hallauer, A. (2001): Speciality Corns (2nd). - New York: CRC Press.

[21] Hartings, H., Berardo, N., Mazzinelli, G., Valoti, P., Verderio, A., Motto, M. (2008): Assessment of genetic diversity and relationships among maize (Zea mays L.) Italian landraces by morphological traits and AFLP profiling. - Theoretical and applied genetics 117(6): 831.

[22] He, H., Yang, L., Fan, L., Zhao, L., Wu, H., Yang, J., Li, C. (2011): The effect of intercropping of maize and soybean on microclimate. - Paper presented at the International Conference on Computer and Computing Technologies in Agriculture.

[23] Ijoyah, M., Fanen, F. (2012): Effects of different cropping pattern on performance of maize-soybean mixture in Makurdi, Nigeria. - Scientific Journal of Crop Science 1(2): $39-47$.

[24] Jamkhanh, A. B., Jelodar, N. B., Abbasian, A., Khorshidi, M. (2012): Study on corn yield and yield component at diffirent levels of nitrogen intercropping corn-soybean. International Kournal of Agriculture and Crop Sciences 4(20): 1477-1487. 
[25] Kan, A., Çoksarı, G., Çelik, S. (2011): Konya Ekolojik Koşullarda Yetiştirilen Farklı Misır (Zea mays L.) Varyetelerinin Bazı Kalite Özellikleri Bakımından Değerlendirilmesi. - 9th Tarla Bitkileri Kongresi 1.

[26] Kaplan, M., Kale, H., Karaman, K., Unlukara, A. (2017): Influence of different irrigation and nitrogen levels on crude oil and fatty acid composition of maize (Zea mays L.). Grasas y Aceites 68(3): 207.

[27] Karagül, E. T., Ay, N., Nazlıcan, A. N. (2011): Ege Bölgesi İkinci Ürün Koşullarında Bazı Soya Fasulyesi (Glycine max (L.) Merr.) Genotiplerinin Verim ve Kalite Özelliklerinin Belirlenmesi. - 9th Tarla Bitkileri Kongresi 2: 839-845.

[28] Kim, M., Song, J. T., Bilyeu, K. D., Lee, J.-D. (2015): A new low linolenic acid allele of GmFAD3A gene in soybean PE1690. - Molecular Breeding 35(8): 155.

[29] Lambert, R. J. (2000): High-oil corn hybrids Specialty Corns, Second Edition. - CRC Press, pp. 143-166.

[30] Lithourgidis, A., Dordas, C., Damalas, C. A., Vlachostergios, D. (2011): Annual intercrops: an alternative pathway for sustainable agriculture. - Australian journal of crop science 5(4): 396.

[31] Lucchin, M., Barcaccia, G., Parrini, P. (2003): Characterization of a flint maize (Zea mays L. convar. mays) Italian landrace: I. Morpho-phenological and agronomic traits. Genetic Resources and Crop Evolution 50(3): 315-327.

[32] Ngalamu, T., Meseka, S., Ashraf, M. (2012): Performance of soybean (Glycine max L. Merrill) genotypes under different planting dates in Sennar State of the Sudan. - Journal of Applied Biosciences 49: 3363-3370.

[33] Olmos, S. E., Trejo, J., Percibaldi, N. M., Eyhérabide, G. (2018): Genetic diversity near the DGAT1-2 gene for high oleic acid content and kernel trait variation in a maize breeding collection. - Molecular Breeding 38(8): 98.

[34] Osang, P. O., Richard, B. I., Iheadindueme, C. A. (2014): Influence of Date of Planting and Time of Introduction of Maize on the Agronomic Performance of Soybean-Maize Intercrop In Nigerian Southern-Guinea Savanna. - Journal of Biology, Agriculture and Healthcare 4(3): 2224-3208.

[35] Öner, F., Gülümser, A., Sezer, İ., Odabas, M. S., Akay, H., Açıkgöz, M. A. (2012): Misır (Zea mays L.) Yaprak Alanının Matematiksel Model ile Tahmin Edilmesi. - Tarım Bilimleri Araştırma Dergisi (1): 128-130.

[36] Raji, J. (2007): Intercropping soybean and maize in a derived savanna ecology. - African Journal of Biotechnology 6(16): 1885-1887.

[37] Ramírez-Moreno, E., Cordoba-Díaz, M., de Cortes Sánchez-Mata, M., Marqués, C. D., Goni, I. (2015): The addition of cladodes (Opuntia ficus indica L. Miller) to instant maize flour improves physicochemical and nutritional properties of maize tortillas. - LWTFood Science and Technology 62(1): 675-681.

[38] Ramos, M. J., Fernández, C. M., Casas, A., Rodríguez, L., Pérez, Á. (2009): Influence of fatty acid composition of raw materials on biodiesel properties. - Bioresource technology 100(1): 261-268.

[39] Sabanc1, İ. (2015): Misır-Soya Birlikte Üretim Şekillerinin Bazı Agronomik Özelliklere Etkisi. - Adnan Menderes Üniversitesi. Fen Bilimleri Enstitüsü, Tarla Bitkileri Anabilim Dalı Doktora Tezi, Aydın.

[40] Sabancı, S. (2016): Ege bölgesinde yetiştirilen bazı mısır (Zea mays L.) çeşitlerinin verim, kalite ve antioksidan aktivitelerinin belirlenmesi. - Adnan Menderes Üniversitesi, Fen Bilimleri Enstitüsü.

[41] Subedi, K., Ma, B. (2005): Ear position, leaf area, and contribution of individual leaves to grain yield in conventional and leafy maize hybrids. - Crop science 45(6): 2246-2257.

[42] Sultan, S. M., Dikshit, N., Vaidya, U. J. (2015): Oil content and fatty acid composition of soybean (Glysine max L.) genotypes evaluated under rainfed conditions of Kashmir Himalayas in India. - Journal of Applied and Natural Science 7(2): 910-915. 
[43] Vartanlı, S., Emeklier, H. (2007): Ankara koşullarında hibrit mısır çeşitlerinin verim ve kalite özelliklerinin belirlenmesi. - Tarım Bilimleri Dergisi 13(3): 195-202.

[44] Wekesa, R., Naliaka, P., Simiyu, J. M. (2015): Seed quality of three soybean varieties as influenced by intercropping time and arrangement in maize. - African Journal of Agricultural Research 10(6): 505-514.

[45] Zhang, Y., Liu, J., Zhang, J., Liu, H., Liu, S., Zhai, L., Yin, C. (2015): Row ratios of intercropping maize and soybean can affect agronomic efficiency of the system and subsequent wheat. - PloS one 10(6): e0129245. 